\title{
PELATIHAN STRATEGI MENCARI DAN MELAMAR PEKERJAAN DI ERA PANDEMI COVID-19 KEPADA ALUMNI PERGURUAN TINGGI
}

\section{Saiful Rahman Yuniarto', Gunawan Eko Nurtjahjono², Raden Rustam Hidayat3, Edy Yulianto4, Muhammad Faisal Riza5}

1,2,3,4,5 Jurusan Ilmu Administrasi Bisnis,Universitas Brawijaya

${ }^{1}$ E-mail address saiful r y@ub.ac.id; 2 E-mail address gunawan fia@ub.ac.id;

3 E-mail address rrustam fia@ub.ac.id ; 4 E-mail address edy y fia@ub.ac.id;

5E-mail address mfaizalriza@ub.ac.id

\begin{abstract}
The high unemployment rate is a fundamental problem in employment in our country, where the new workforce that is added is far greater than the increase in employment. Unemployment is a problem for countries with high population growth rates, and unemployment can also affect the level of the economy. At the beginning of 2020, world economic growth experienced a decline due to the coronavirus disease outbreak, this coronavirus (covid19) had an impact on economic growth in the form of a decline in the level of the world economy, including Indonesia. Seeing conditions like this, special attention is needed for alumni to prepare students for the world of work.

This community service is carried out in the form of training on strategies for finding and applying for jobs, the problem solving framework provided is by providing training so that it can increase knowledge and insight to job seekers college alumni about srategies for finding and applying for jobs.The purpose of this community service activity is to provide training to college alumni so that they have the readiness to find and apply for jobs. This community service activity is carried out virtually online online in the form of training and guidance. The target is college alumni who will definitely be involved in the activity of finding and applying for jobs, at the initial stage the presenter will deliver a theoretical presentation accompanied by realistic examples.

The results of the implementation of community service by providing the training are expected that college alumni as prospective job seekers already have the knowledge, insight and readiness in finding and applying for jobs, then to provide knowledge and insight about strategies for finding and applying for these jobs, as well as the factors that must be considered.
\end{abstract}

Keywords: Student Alumni, Job Seeker, Covid-19 


\begin{abstract}
Abstrak
Tingkat pengangguran yang tinggi merupakan masalah mendasar dalam ketenagakerjaan di negara kita, dimana tenaga kerja baru yang bertambah jauh lebih besar dibandingkan dengan pertambahan lapangan pekerjaan. Pengangguran menjadi masalah bagi negara yang tingkat pertumbuhan penduduknya tinggi, dan pengangguran juga bisa mempengaruhi tingkat perekonomian. Pada awal tahun 2020, pertumbuhan ekonomi dunia mengalami penurunan dikarenakan adanya wabah coronavirus disease, coronavirus (covid-19) ini memiliki dampak bagi pertumbuhan ekonomi yang berupa menurunya tingkat perekonomian dunia termasuk Indonesia. Melihat kondisi seperti ini maka diperlukan perhatian khusus bagi alumni lulusan mahasiswa untuk mempersiapkan bekal dalam menghadapi dunia kerja.

Pengabdian kepada masyarakat ini dilakukan dalam bentuk pelatihan tentang strategi mencari dan melamar pekerjaan, kerangka pemecahan masalah yang diberikan adalah dengan cara memberikan pelatihan sehingga dapat meningkatkan pengetahuan dan wawasan kepada alumni perguruan tinggi pencari kerja tentang strategi mencari dan melamar pekerjaan. Tujuan kegiatan pengabdian kepada masyarakat ini adalah memberikan pelatihan kepada alumni perguruan tinggi agar mereka mempunyai kesiapan dalam mencari dan melamar pekerjaan, dengan kegiatan pelatihan tersebut diharapkan alumni perguruan tinggi nantinya harus siap dalam mencari dan melamar pekerjaan. Kegiatan pengabdian kepada masyarakat ini dilaksanakan secara virtual online daring dalam bentuk pelatihan dan bimbingan yang menjadi sasarannya adalah alumni perguruan tinggi yang nantinya pasti terlibat dalam aktifitas mencari dan melamar pekerjaan, pada tahap awal pemateri akan menyampaikan pemaparan dalam bentuk teoritis dengan disertai contoh yang realistis, selanjutnya tahap berikutnya akan ada sesi diskusi dan tanya jawab dengan peserta pelatihan.

Hasil pelaksanaan pengabdian masyarakat dengan memberikan pelatihan tersebut diharapkan alumni perguruan tinggi sebagai calon pencari kerja sudah mempunyai pengetahuan, wawasan dan kesiapan dalam mencari dan melamar pekerjaan, selanjutnya untuk memberikan pengetahuan dan wawasan tentang strategi mencari dan melamar pekerjaan tersebut, serta faktor-faktor yang harus diperhatikan dan diperhitungkan dalam mencari pekerjaan, strategi dalam mencari dan melamar pekerjaan, dan hal-hal apa saja yang harus diperhatikan oleh para pencari kerja.
\end{abstract}

Kata Kunci: Alumni Mahasiswa, Pencari Kerja, Covid-19

\section{PENDAHULUAN}

Keberhasilan pembangunan suatu negara dilihat dari beberapa indikator, salah satu indikator penting dalam keberhasilan pembangunan negara yakni pertumbuhan ekonomi dan tingkat pengangguran. Pertumbuhan ekonomi merupakan pendapatan negara yang mengalami kenaikan secara nasional agregatif ataupun peningkatan output dalam suatu periode tertentu, makna lainnya dari pertumbuhan ekonomi yakni 
pertumbuhan ekonomi yang menunjukkan peningkatan kapasitas produksi dalam barang dan jasa dengan fisik sesuai pada kurun waktu tertentu. Pertumbuhan tersebut dapat diketahui melalui bertambahnya produksi barang industry, jumlah sekolah, berkembangnya infrastruktur, bertambahnya sektor jasa serta bertambahnya produksi barang modal. Setiap negara akan berupaya untuk menaikkan dan memberikan hal yang terbaik guna mendukung pertumbuhan ekonomi negara dengan optimal. Termasuk Indonesia yang merupakan salah satu negara berkembang yang berupaya menaikkan pertumbuhan ekonominya guna kesejahteraan masyarakat dan kehidupan yang lebih baik.

Kondisi di negara berkembang seperti Indonesia pertumbuhan ekonomi yang dicapai juga diiringi dengan meningkatnya jumlah penduduk Indonesia, dimana jumlah penduduk masih banyak yang menjadi pengangguran, berdasarkan dari Badan Pusat Statistik (BPS) tingkat pengangguran terbuka pada tahun 2020 bulan Februari 2020 tercatat sebesar 05,01\%. Pengangguran merupakan selisih antara angkatan kerja dengan penggunaan tenaga kerja yang sebenarnya. Sedangkan tingkat pengangguran terbuka sendiri diartikan sebagai prosentase jumlah pengangguran terhadap jumlah angkatan kerja. Pengangguran terbuka terdiri dari orang yang tidak mempunyai pekerjaan dan mencari pekerjaan, orang yang tidak mempunyai pekerjaan dan mempersiapkan usaha, orang yang tidak mempunyai pekerjaan dan tidak mencari pekerjaan karena merasa tidak mungkin mendapatkan pekerjaan, serta orang yang sudah mempunyai pekerjaan tetapi belum memulai bekerja.

Tingkat pengangguran yang tinggi merupakan masalah mendasar dalam ketenagakerjaan di negara kita, dimana tenaga kerja baru yang bertambah jauh lebih besar dibandingkan dengan pertambahan lapangan pekerjaan, artinya lapangan pekerjaan yang tersedia belum memenuhi tingkat tenaga kerja yang ada di Indonesia, sehingga menimbulkan tingkat pengangguran yang tinggi. Pengangguran menjadi masalah bagi negara yang tingkat pertumbuhan penduduknya tinggi, pengangguran juga bisa mempengaruhi tingkat perekonomian, hal ini dikarenakan pendapatan negara juga akan berkurang karena pendapatan nasional negara diukur dari prosentase jumlah seluruh pendapatan masyarakat Indonesia yang berpenghasilan dibagi dengan jumlah 
seluruh penduduk Indonesia. Jika jumlah penghasilan lebih sedikit maka rata-rata pendapatan nasional negara akan lebih kecil karena jumlah penduduk belum sebanding dengan jumlah pendapatan nasional, oleh karena itu pengangguran menjadi suatu permasalahan jangka pendek suatu negara.

Pada awal tahun 2020, pertumbuhan ekonomi dunia mengalami penurunan dikarenakan adanya wabah coronavirus disease. Coronavirus adalah virus yang menyebabkan penyakit mulai dari gejala ringan sampai gejala berat. Pada tanggal 11 Maret 2020 WHO sebagai Organisasi Kesehatan Dunia resmi mengumumkan bahwa wabah coronavirus sebagai pandemic global, coronavirus (covid-19) ini memiliki dampak bagi pertumbuhan ekonomi yang berupa menurunya tingkat perekonomian dunia termasuk Indonesia.

Melihat kondisi fenomena diatas, maka diperlukan perhatian khusus bagi alumni lulusan mahasiswa untuk mempersiapkan bekal dalam menghadapi dunia kerja, dimana mendapat predikat alumni lulusan mahasiswa terbaik dari suatu universitas bukan menjadi jaminan untuk bisa langsung diterima bekerja, dimana Indeks Prestasi (IP) tinggi diatas 3,5 pun bukan jaminan bagi para sarjana segera mendapatkan pekerjaan. Mereka harus keluar kantor mengantarkan lamaran dengan harapan ada lowongan pekerjaan untuk mereka, malahan dengan alasan mencari pengalaman dulu, para sarjana itu rela bekerja apa saja meski bergaji kecil dan tidak sesuai dengan ilmu yang dipelajari, mereka tidak ingin mendapatkan gelar baru yakni "pengangguran", itulah fenomena yang banyak kita saksikan di tengah kehidupan masyarakat. Dimana sekarang ini banyak sekali alumni lulusan mahasiswa perguruan tinggi yang sulit mendapatkan pekerjaan.

Pencari kerja yang baru saja lulus seringkali memiliki semangat yang kuat untuk mencari kerja, antusiasme dan semangat seperti ini patut dikagumi, akan tetapi terdapat beberapa kesalahan yang seringkali dipicu oleh antusiasme berlebihan seorang job seeker. Memang hal ini tidak akan menghancurkan kesempatan karir di masa depan, tetapi paling tidak kesalahan berikut ini akan memberikan sedikit kekhawatiran pada kesempatan untuk mendapatkan pekerjaan yang baik di awal karir. Hal inilah yang harus diperhatikan oleh alumni lulusan mahasiswa agar tidak melakukan kesalahan dalam mendapatkan pekerjaan.

Berdasarkan fenomena tentang banyaknya pengangguran di Indonesia 
dan sulitnya mencari pekerjaan, menjadikan hal yang menarik dan bermanfaat untuk memberikan pelatihan kepada alumni lulusan mahasiswa untuk mempersiapkan dirinya agar dapat bersaing dalam mencari dan melamar pekerjaan sehingga mendapatkan pekerjaan yang diinginkan. Namun bukan berarti alumni lulusan mahasiswa hanya berpikir sebagai pencari kerja saja, namun harus aktif berperan menciptakan lapangan pekerjaan, sebagai salah satu solusi mengatasi masalah yang dihadapi alumni terutama lulusan perguruan tinggi.

Sasaran dan target pelatihan ini adalah alumni dengan asumsi mereka sudah menyelesaikan pekerjaan dan siap melamar pekerjaan. Peserta pelatihan akan mengikuti acara pelatihan ini dengan sungguh-sungguh sesuai jadwal yang telah ditentukan. Semua peserta pelatihan mendapatkan materi yang sama dengan harapan mereka mempunyai pemahaman yang sama dengan materi yang disampaikan dan kemudian dapat dilakukan pengembangan dan pemberian contoh oleh pemateri pelatihan.

\section{METODE DAN PELAKSANAAN}

\section{Metode}

Metode Pelaksanaan Pengabdian Kepada Masyarakat yakni dalam bentuk
Pelatihan Daring yang dilaksanakan secara virtual online yang menjadi sasarannya adalah alumni perguruan tinggi yang nantinya pasti terlibat dalam aktifitas mencari dan melamar pekerjaan, pada tahap awal pemateri akan menyampaikan pemaparan materi tentang strategi mencari dan melamar pekerjaan dalam bentuk teoritis dengan disertai contoh yang realistis, selanjutnya tahap berikutnya akan ada sesi diskusi dan tanya jawab dengan peserta pelatihan.

\section{Pelaksanaan Kegiatan}

Kegiatan pengabdian kepada masyarakat ini dilaksanakan mulai persiapan pada bulan juli sampai dengan September serta pelaksanaan pada tanggal 7 Oktober 2021 Pukul 09.00 sampai dengan pukul 15.00 yang diikuti kurang lebih 150 peserta pelatihan.

\section{HASIL DAN PEMBAHASAN}

Dengan rencana, realisasi dan kerangka pemecahan masalah yang telah dilaksanakan menunjukkan bahwa kegiatan pengabdian kepada masyarakat ini telah berjalan sesuai dengan tujuan, sasaran serta manfaat yang telah direncanakan. Materi pelatihan ini diharapkan dapat membekali alumni yang nantinya pasti akan terlibat dalam 
aktifitas mencari dan melamar pekerjaan. Dengan kegiatan ini diharapkan alumni sudah mempunyai pengetahuan dan pengalaman bagaimana sebenarnya strategi dalam mencari dan melamar pekerjaan, terkait hal-hal apa saja yang harus diperhatikan dalam melamar pekerjaan, sehingga setelah tiba waktunya nanti untuk melamar pekerjaan sudah siap dalam melamar pekerjaan. Adapun materi yang disampaikan kepada peserta pelatihan yakni dibagi dalam empat sesi yakni sebagai berikut :

1. Pada Sesi Pertama dilakukan penjabaran dan penjelasan materi tentang : pengangguran, harapan dari pemateri ini adalah agar alumni mengetahui seperti apa pengangguran itu, macam-macam pengangguran dan apa yang harus dilakukan agar tidak menjadi pengangguran.

2. Pada Sesi Kedua, dijelaskan tentang materi faktor-faktor yang harus diperhatikan dalam mencari kerja, dengan pemberian materi ini diharapkan mahasiswa mempunyai pengetahuan dan wawasan faktorfaktor apa yang harus diperhatikan dalam mencari kerja, sehingga nantinya mereka dapat mempersiapkan diri dalam mencari kerja.
3. Pada Sesi Ketiga, materi yang diberikan adalah strategi melamar pekerjaan. Dalam materi strategi mencari kerja ini diberikan penjelasan tentang apa yang harus dilakukan ketika mau mencari pekerjaan dan bagaimana cara kita dalam mencari pekerjaan serta strategi apa yang harus kita lakukan.

4. Pada Sesi Keempat, materi yang disampaikan adalah perihal yang harus menjadi perhatian para alumni pencari kerja.

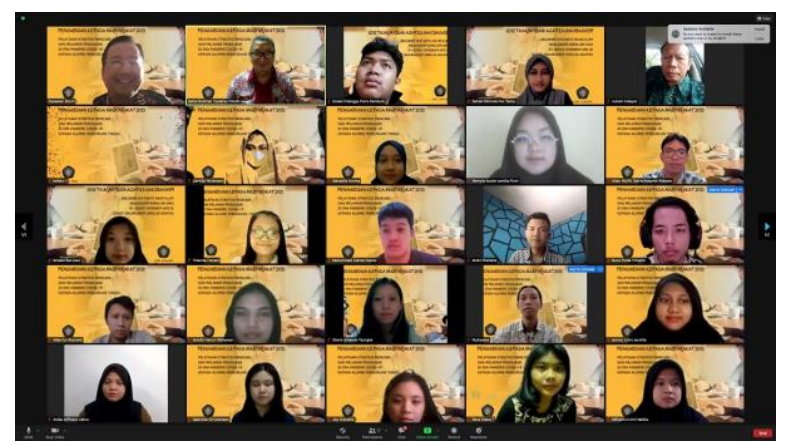

Gambar 1. Penyampaian Materi

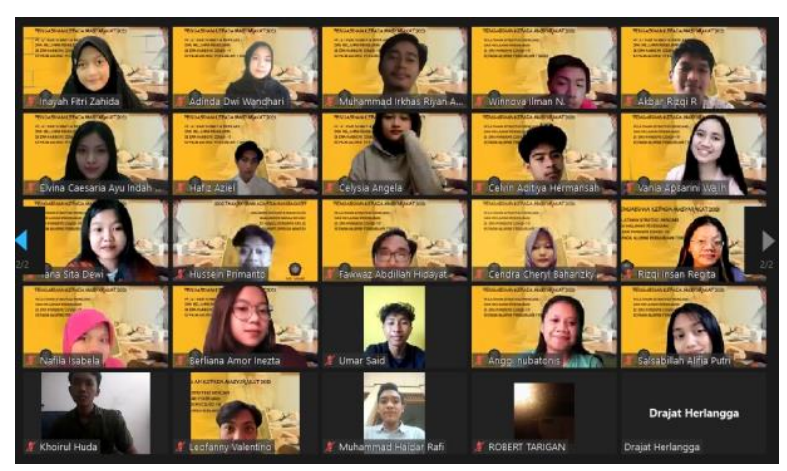

Gambar 2. Peserta pelatihan

\section{PENUTUP}

Kegiatan pengabdian kepada masyarakat dalam bentuk pelatihan strategi mencari dan melamar pekerjaan kepada alumni perguruan tinggi di masa 
Covid-19 ini dilaksanakan secara virtual/on line dan berjalan dengan lancar meskipun terdapat beberapa kendala jaringan sinyal peserta pelatihan, dan peserta pelatihan mengikuti pelatihan ini sangat antusias dengan mengajukan beberapa pertanyaan kepada pemateri pelatihan.

\section{Simpulan}

Kegiatan pelatihan strategi mencari dan melamar pekerjaan bagi alumni perguruan tinggi ini berjalan dengan lancar, meskipun ditemui beberapa kendala dalam pelatihan via on line/daring, seperti terkendala jaringan dan sinyal peserta pelatihan dalam mengikuti kegiatan pelaksanaan pengabdian kepada masyarakat. Terkait dengan antusias peserta pelatihan, mereka sangat aktif hal ini dibuktikan dengan antusias yang tinggi dirasakan oleh para peserta pelatihan yang hadir dalam kegiatan pelatihan via daring/on line.

\section{Saran}

Dari kegiatan pelatihan ini terdapat beberapa saran dan kontribusi yang bisa diberikan yakni :

1. Kegiatan pengabdian masyarakat dengan kegiatan pelatihan dapat dikembangkan dengan menambah materi kemampuan keterampilan mengoperasionalkan komputer sebagai salah satu keunggulan didalam mencari dan melamar pekerjaan.

2. Kegiatan pengabdian masyarakat dengan kegiatan pelatihan ini juga bisa mengundang stakeholder dalam hal ini pimpinan perusahaan agar bisa mensinergikan antara para pencari kerja dalam hal ini alumni dengan para penerima kerja dalam hal ini pimpinan perusahaan.

3. Kegiatan pengabdian masyarakat dengan kegiatan pelatihan ini juga bisa melibatkan para mahasiswa yang sudah menyelesaikan teorinya tinggal menunggu ujian siding skripsi, agar mereka juga bisa jauh hari mempersiapkan kemampuan mereka didalam mengikuti seleksi dan wawancara kerja.

\section{Ucapan Terima Kasih}

Kami sangat berterima kasih kepada pihak-pihak yang terkait dalam pengabdian kepada masyarakat seperti Pimpinan Fakultas, Pimpinan Lembaga Penelitian dan Pengabdian Kepada Masyarakat, Alumni Mahasiswa atas partisipasinya dalam mengikuti acara pelatihan strategi mencari dan melamar pekerjaan di era pandemic Covid-19. 
Semoga Pelatihan yang telah dilaksanakan dapat bermanfaat dan diaplikasikan oleh seluruh alumni perguruan tinggi dalam mencari dan melamar pekerjaan.

\section{DAFTAR PUSTAKA}

Murni, Asfia, 2009, Ekonomika Makro, PT.Refika Aditama : Bandung.

Payaman, J Simanjutak, 1985, Pengantar Ekonomi Sumber Daya Manusia, Penerbit FE UI, Jakarta

Ubaydillah, AN, 2009, Modal Utama Mencari Kerja, Industri
Windiarto, Bangun, 2009, Modal Utama Pencari Kerja, UGM News

Badan Pusat Statistik di akses dari www.bps.go.id

Sukirno, Sadono, 2008, Ekonomi Pembangunan, Yogyakarta; BPFE Yogyakarta.

Satuan Tugas Penanganan Covid-19 diakses dari www.covid-19.co.id 